\title{
Integration of Portable Sedimentary Microbial Fuel Cells in Autonomous Underwater Vehicles
}

\author{
Giulia Massaglia ${ }^{1,2, *(\mathbb{D}}$, Adriano Sacco ${ }^{2} \mathbb{D}$, Alain Favetto ${ }^{2}$, Luciano Scaltrito ${ }^{1}$, Sergio Ferrero ${ }^{1}$, Roberto Mo ${ }^{1}$, \\ Candido F. Pirri ${ }^{1,2}$ (D) and Marzia Quaglio $1,2, *$
}

1 Department of Applied Science and Technology, Politecnico di Torino, 10129 Torino, Italy; luciano.scaltrito@polito.it (L.S.); sergio.ferrero@polito.it (S.F.); roberto.mo@polito.it (R.M.); fabrizio.pirri@polito.it (C.F.P.)

2 Center for Sustainable Future Technologies@ POLITO, Istituto Italiano Di Tecnologia, 10144 Torino, Italy; adriano.sacco@iit.it (A.S.); alain.favetto@gmail.com (A.F.)

* Correspondence: giulia.massaglia@polito.it (G.M.); marzia.quaglio@polito.it (M.Q.)

Citation: Massaglia, G.; Sacco, A.; Favetto, A.; Scaltrito, L.; Ferrero, S.; Mo, R.; Pirri, C.F.; Quaglio, M. Integration of Portable Sedimentary Microbial Fuel Cells in Autonomous Underwater Vehicles. Energies 2021, 14, 4551. https://doi.org/10.3390/ en14154551

Academic Editor: Nicu Bizon

Received: 23 June 2021

Accepted: 24 July 2021

Published: 28 July 2021

Publisher's Note: MDPI stays neutral with regard to jurisdictional claims in published maps and institutional affiliations.

Copyright: (c) 2021 by the authors. Licensee MDPI, Basel, Switzerland. This article is an open access article distributed under the terms and conditions of the Creative Commons Attribution (CC BY) license (https:// creativecommons.org/licenses/by/ $4.0 /)$.
Abstract: In the present work, sedimentary microbial fuel cells (s-MFC) have been proposed as effective tools to power remote sensors in different aquatic environments, thanks to their ability to produce renewable and sustainable energy continuously and autonomously. The present work proposes the optimization of cylindrical sedimentary microbial fuel cells (s-MFC) as a compact and cost-effective system suitable to be integrated as a payload in an Autonomous Underwater Vehicle (AUV). To this purpose, a new AUV payload, named MFC-payload, is designed to host the cylindrical s-MFC and a data acquisition system to collect and store information on the voltage produced by the cell. Its overall performance was evaluated during two field measurement campaigns carried out in the Mediterranean Sea. This investigation demonstrates the power production by s-MFC during operation of the AUV in seawater and analyzes the actual influence of environmental conditions on the output power. This study demonstrates that energy production by s-MFCs integrated in AUV systems is decoupled by the navigation of the autonomous vehicle itself, showing the effectiveness of the application of MFC-based technology as a power payload for environmental analysis. All these latter results demonstrate and confirm the ability of the devices to continuously produce electricity during different AUV operation modes (i.e., depth and speed), while changing environmental conditions (i.e., pressure, temperature and oxygen content) demonstrate that cylindrical s-MFC devices are robust system that can be successfully used in underwater applications.

Keywords: microbial fuel cells; sedimentary MFC; floating MFC; autonomous underwater vehicles; MFC-payload

\section{Introduction}

During recent years, an increasing interest into the development and design of Autonomous underwater vehicles (AUVs) has occurred. AUVs can be defined as uncrewed, untethered, underwater vehicles, characterized by self-propulsion, which are mainly employed for underwater surveys, such as oceanographic, commercial and military missions [1-4]. In particular, the majority of these vehicles show mobile instrumentation platforms with actuators, sensors and on-board intelligence, with the main aim of performing survey and sampling tasks autonomously, i.e., without human supervision. AUVs are primarily used for seabed mapping by different sonar-based imaging tools and for water column analysis of different parameters, such as temperature, salinity, $\mathrm{pH}$, oxygen content, bioluminescence and a wide range of inherent optical properties [3,5-9]. Several works in the literature [3,5-9] have identified energy storage capacity, propulsion system efficiency, hydrodynamic attributes of the vehicle hull, vehicle guidance and navigation accuracy as the main technological factors influencing the maximum endurance for a specific AUV mission. Indeed, defining an AUV's mission means precisely fixing requirements such 
as nominal speed, maximum depth, the specific payload necessary for the mission and endurance. All these requirements affect each other, but endurance is strictly correlated to the available stored energy [10]. Batteries are the technology of reference for energy storage in AUVs, and interest is high in advancements in this technology [10-14]. Despite the significant improvements in this class of energy storage devices, they suffer the limitation of intrinsic low energy density which hinders the prolonged underwater operations of AUVs [1]. To overcome this severe technical barrier, different energy storage strategies have started to attract interest, and sustainable and renewable energy sources have emerged as a potent option [15]. Among all renewable energy technologies, such as solar energy [16-19], wave energy [20-24], and wind energy [24-26], fuel cell technologies represent an intriguing storage option [27]. A particular class of fuel cells, classified as bio-energy sources, is based on Microbial Fuel Cells (MFCs). MFCs are versatile bio-electrochemical systems able to produce electrical energy autonomously, continuously and safely. Given their unique features, successful integration of MFCs in robotic systems has already been demonstrated [28]. MFCs are indeed able to produce electrical energy starting from chemical energy trapped in the organic matter (i.e., fuel) available in different substrates [29]. Differently from common fuel cells, in MFCs electroactive microorganisms, which are able to proliferate under anaerobic conditions, leading thus to the creation of biofilms in intimate contact with the anodic electrode [30], carry out the oxidation of the fuel or organic matter. Electroactive bacteria are able to catalyze the oxidation reaction of organic compounds, releasing electrons which can flow from the anode to the cathode through an external load. At the cathode, the circuit is closed through a reduction reaction, usually involving molecular oxygen, often in the presence of a Pt-based catalyst to speed up the reaction [31]. A key role is played by the metabolic activity of electroactive bacteria in the working principle of MFCs, making them intrinsically sensitive to variations in the environmental parameters [32-34]. Furthermore, using oxygen as the electron acceptor offers significant advantages to simplify MFCs' architecture and operation mode, making them suitable for a wider range of applications [35-38]. As concerns the employment of MFCs in aquatic environments, different works in the literature have focused their attention on two main configurations: (i) sedimentary microbial fuel cells (s-MFCs), where the organic matter present in sediments was directly used as fuel for the metabolic activity of microorganisms and (ii) floating microbial fuel cells (f-MFCs), which exploited organic compounds available in seawater $[39,40]$. Both kinds of device were able to produce renewable and sustainable energy continuously and autonomously [39-45].

In the present work, we investigate s-MFC with the main aim of designing a compact, cost-effective and sustainable energy unit suitable to be integrated as a novel MFC-payload in a modular Autonomous Underwater Vehicle (AUV). Moreover, we demonstrate the capability of applying s-MFcs as new reservoirs for powering robotic platforms, such as an AUV glider. Actually, during the last twenty years, pioneering works from Wilkinson, Melhuish, and Ieropoulos successfully demonstrated the possibility of integrating MFCs in robotic systems as the sole power source [28,46-48]. Differently from the above, the goal of the present work is to demonstrate how s-MFCs, integrated in AUV, can help extend the duration of autonomous activities, by providing a continuous source of blue, clean and sustainable energy.

To the best of our knowledge, this is first application of s-MFCs that provides, at the same time, an energy production tool and sensor capability in an AUV system, leading thus to correlate s-MFCs' power variation with the environmental conditions. Indeed, in the present work, we propose to analyze the power production of s-MFC during operation of the AUV in seawater, especially with the aim of understanding the possible influence of environmental conditions on the power output. To this purpose, we optimized a cylindrical architecture made of an inner-chamber, adapted to work as the anodic chamber, and an outer-shell, working as the cathode. In this configuration, the anode is completely buried in sediment, which is rich in organic matter, while the cathode is suspended in overlying water, as sketched in Scheme 1. The anoxic conditions are preserved at the anode due to 
the presence of the sediment, where the anode electrodes were completely buried [49]. The device can work for a long time with low or null maintenance costs $[49,50]$. Moreover, in the present work, we provided an in-situ pre-colonizing enrichment approach, allowing the induction of a proliferation of marine microorganisms onto carbon-based material, directly into sea environments [40]. Onto the cathode electrodes, no catalyst layer was applied, guaranteeing spontaneously aerobic biofilm formation, which plays a crucial role in catalyzing the oxygen reduction reaction, as confirmed by several works [51,52]. Preliminary tests in our laboratory were performed to optimize s-MFCs, which can be successively hosted into the newly designed AUV payload, named the MFC-payload, represented in Scheme 1.

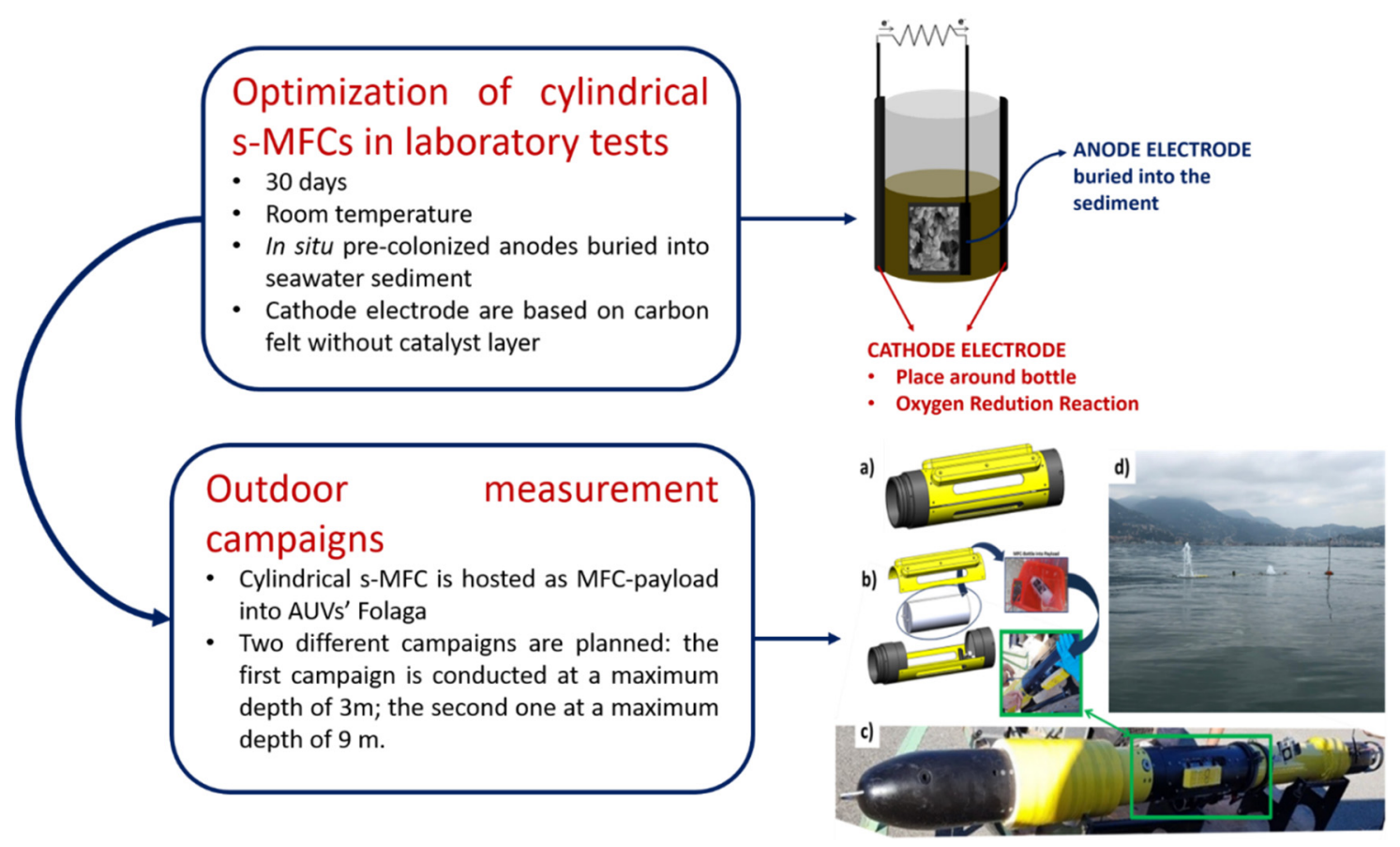

Scheme 1. Structure of the work. In our laboratory, the development and optimizations of cylindrical s-MFCs occurred; subsequently 2 outdoor campaigns were planned and cylindrical s-MFCs were integrated in AUV's folaga as MFC-payload. The details of AUV's folaga were reported in (a) complete housing for s-MFC; (b) the integration of s-MFC into MFC-payload; (c) the complete AUV's folaga assembled; (d) an example of outdoor campaign in La Spezia Bay.

After development in the lab, preliminary analysis of the performance of the cylindrical s-MFCs was evaluated during a measurement campaign carried out in the Mediterranean Sea in a static condition, i.e., not yet integrated into the AUV. The overall performance of the cylindrical s-MFC integrated in the MFC-payload was then analyzed during two measurement campaigns: the first one to test the behavior at a maximum depth of $3 \mathrm{~m}$, and the second one to test the performance of the new MFC-payload up to $9 \mathrm{~m}$ of depth. These depths were selected with the purpose of investigating the behavior of s-MFCs as a stable MFC-payload, evaluating the impact of environmental external parameters, such as $\mathrm{pH}$ values, sea-water temperature, sea-water conductivity, and salinity on the energy output of s-MFCs $[53,54]$.

All these parameters were measured at different depths in the range from $0 \mathrm{~m}$, corresponding to water-surface, to $6 \mathrm{~m}$ from sea surface. As summarized in Table 1, the slight variations in all environmental parameters along these depths led to the evaluation of the robustness and capability of optimized cylindrical s-MFC to continuously produce electricity during underwater applications. Indeed, several works in the literature have focused their attention on the microbial fuel cells implemented as new reservoirs for powering robotic platforms, such as the AUV glider proposed in the present work [55]. A great interest in the provision of energy via microbial fuel cells in the field of marine biomimicking 
robotic research is growing [55]. The bottleneck in this scenario is represented by the lack of long-lasting energy provision, needed to achieve the conditions for the robots' operation autonomy. To the best of our knowledge, this is the first time that a cylindrical sedimentary MFC was applied in an AUV glider during its operation mode. This latter consideration implies that the strict correlation between operation modes of the AUV glider and the s-MFC's performance has still not been deeply investigated.

Table 1. External parameters measured at different depths in the range from $0 \mathrm{~m}$, corresponding to water-surface, to $6 \mathrm{~m}$ from sea-surface.

\begin{tabular}{ccccc}
\hline Depth [m] & Temperature $\left[{ }^{\circ} \mathbf{C}\right]$ & $\begin{array}{c}\text { Conductivity } \\
{[\mathbf{m S} / \mathbf{c m})}\end{array}$ & Salinity [ppt] & pH Values \\
\hline 0 & $26.65 \pm 0.02$ & $58.98 \pm 0.08$ & $38.11 \pm 0.02$ & 8.06 \\
\hline 1 & $18.72 \pm 0.01$ & $50.09 \pm 0.02$ & $37.95 \pm 0.01$ & 7.99 \\
\hline 3 & $13.28 \pm 0.03$ & $41.46 \pm 0.21$ & $35.21 \pm 0.22$ & 7.64 \\
\hline 6 & $13.07 \pm 0.08$ & $37.74 \pm 0.77$ & $31.88 \pm 0.76$ & 7.79 \\
\hline
\end{tabular}

With the main purpose of implementing s-MFCs as new reservoirs for powering robotic platforms, such as AUV gliders, the parameter of recovered energy (Erec) at each depth was defined [55-57], leading thus to demonstrate the capability of s-MFCs to produce power output for the whole period and in different environmental conditions.

All the obtained results allowed analysis of how environmental parameters can affect the behavior of cylindrical s-MFCs integrated in the MFC-payload.

Concerning the environmental conditions, many works in the literature explain how the pressure, temperature and oxygen content can be affected by the biofilm formation, the microbial activity, and consequently affect MFCs' performance [40]. Nevertheless, how the factors affect microbial community assembly and their effects on the performance of bio-electrochemical systems are poorly understood [58-60]. Heidrich et al. demonstrated how the temperature affects overall performance less, especially when complex wastewater was used [58]. On the contrary, substrate presents the most significant effect on both reactor performance and diversity. Other important environmental parameters that affect s-MFCs' performance are conductivity and the $\mathrm{pH}$ value of the solution. The conductivity of the solution and the rate of ion transfer are strictly correlated, leading thus to demonstrate how a higher conductivity improves the ionic conductivity, reducing thus the Ohmic losses into the devices and consequently enhancing the overall performance [60]. Concerning $\mathrm{pH}$ values, however, is the high adaptability of anodic marine consortia even in extreme conditions of $\mathrm{pH}$ [61]. In the present work, all obtained results demonstrate the ability of these devices to continuously produce electricity during different AUV operation modes (i.e., depth and speed) and in changing environmental conditions (i.e., temperature, salinity of solution, conductivity of solution and $\mathrm{pH}$ values), leading thus to demonstrate that cylindrical s-MFC devices are robust systems that can be successfully used in underwater applications.

\section{Materials and Methods}

The aim of this work is the design of a novel MFC-payload. The FOLAGA AUV-glider system (by GraalTech srl, Genoa, Italy) was selected as reference for the design. All the tests described in this work using the novel MFC-payload were performed with the selected FOLAGA AUV-glider.

\subsection{Structure of the Work/Laboratory Experiments}

As reported in Scheme 1, the workflow was characterized by two principal parts: part 1 the laboratory optimization of cylindrical sedimentary Microbial Fuel Cells (s-MFCs) and part 2 the integration and testing of the optimized cylindrical s-MFCs as the novel MFC-payload of the selected AUV. In particular, the second part of the experiments was 
performed in situ, in La Spezia Bay (Ligurian Sea) during two different campaigns. In the present work, the s-MFC is characterized by a cylinder made of high-density polypropylene (HDPP); the inner volume was used as the inner anodic chamber of the cell, while the cathode was placed on the outer shell. The HDPP wall of the cylinder ensured the electrical insulation between anode and cathode electrodes, as sketched in Scheme 1, while the hydraulic connection between the chambers was possible by making holes through the same wall. The final system is membrane-less. In this configuration, anode electrodes were made of commercial carbon felt with a nominal geometric area of $5.76 \mathrm{~cm}^{2}$ (Soft felt SIGRATHERM GFA5, SGL Carbon). Total anodic surface area equals $18 \mathrm{~cm}^{2}$. They were completely buried in sediment, allowing thus to preserve the anoxic conditions suitable for bacteria proliferation. In particular, as described in our previous work [40], all anodes were previously colonized by an in-situ pre-colonization enrichment approach based on leaving the electrodes buried in seawater sediment at $3 \mathrm{~m}$ underwater for $1 \mathrm{month}$. This process induced the spontaneous formation of a biofilm based on microorganisms typical of a marine environment. [40] Total internal volume of s-MFC is $1 \mathrm{~L}$. Moreover, half of the total volume was directly occupied by seawater sediment, while the remaining volume was filled by seawater with different dissolved compounds, such as $2.5 \mathrm{~g} \mathrm{~L}^{-1}$ of sodium acetate used as carbon energy source and $0.75 \mathrm{~g} \mathrm{~L}^{-1}$ of ammonium chloride, provided as nitrogen source and able to sustain the metabolic activity of bacteria. During the whole experimental period in the laboratory, when the voltage drops were registered, the seawater was exchanged with new water without adding any artificial nutrient, allowing the MFCs to use only natural nutrients available in seawater. Cathode electrodes were also based on commercial carbon felt (nominal geometric area of $30 \mathrm{~cm}^{2}$ ) without any catalyst layer, and the ORR reaction was performed by the aerobic biofilm that spontaneously grew onto cathode electrodes [51-53]. In this configuration, cathode electrodes were placed on the outer side of the cylindrical s-MFCs and fixed by tie-wraps to the cylindrical structure and in contact with seawater, with the main aim of using oxygen dissolved in sea water as the terminal electron acceptor for a direct oxygen reduction reaction. Anode and cathode electrodes were connected by an external load, equal to $680 \Omega$, corresponding to the best s-MFCs' performance achieved, as confirmed by our previous work [40]. During laboratory experiments, the whole devices were immersed into a container filled with seawater, with the aim of mimicking the marine environment. Titanium wires, threaded along the electrodes, were used to guarantee a good electrical contact. All laboratory experiments were conducted in triplicate and overall s-MFC's performance were evaluated. Both anode and cathode were connected with a multichannel data acquisition unit (Agilent 34972A).

Polarization curves were obtained through linear sweep voltammetry (LSV, performed by using a biologic VSP potentiostat) with a rate of $0.1 \mathrm{mV} \mathrm{s}^{-1}$. The whole period of investigation lasted one month.

\subsection{Development of s-MFCs as Payload}

Concerning the second part of the work, cylindrical s-MFC can be hosted into the new designed AUV payload, named the MFC-payload. The payload was conceived with holes to allow continuous contact with seawater during the operation, as reported in Figure 1a. The optimized cylindrical s-MFC is depicted in Figure 1b, highlighting the cathode electrodes distributed along the external side of the cylindric bottle. The whole AUV system is mounted as reported in Figure 1c where the MFC-payload is highlighted by the green box. 


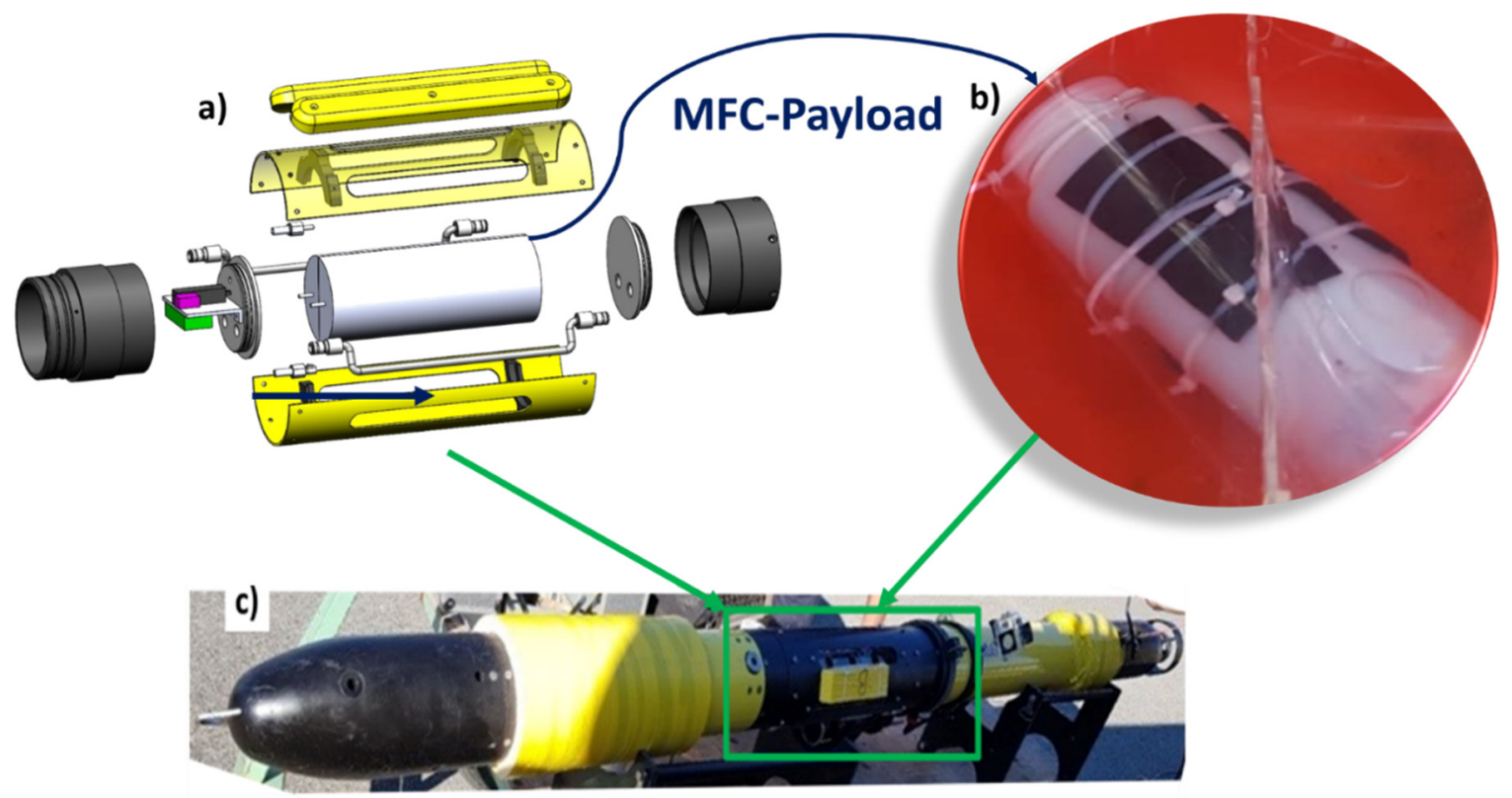

Figure 1. Representation of the Folaga AUV-glider and integration of cylindrical s-MFC as MFC-payload: (a) 3D-render of the MFC-payload, (b) pictures showing the s-MFC assembly, (c) the final AUV-Glider system with the newly MFC-payload.

A preliminary analysis of the performance of the cylindrical s-MFCs was evaluated during a measurement campaign carried out in the Mediterranean Sea in a static condition, i.e., not yet integrated in the AUV. The overall performance of the cylindrical s-MFC integrated in the MFC-payload was then analyzed during two measurement campaigns: the first one to test the behavior at a maximum depth of $3 \mathrm{~m}$, and the second one to test the performance of the new MFC-payload up to $9 \mathrm{~m}$ of depth. The results demonstrate a high stability of the cylindrical s-MFC integrated in the MFC-payload. With the main purpose of investigating the capability of s-MFCs to continuously produce energy during different AUV operation modes, overall performance of s-MFCs were monitored during the whole mission. Moreover, another physical parameter, recovered energy $\left(E_{r e c}\right)$, was introduced $[50,51]$. $E_{\text {rec }}$ was defined, integrating the measured power output over batch treatment time, according to the Equation (1). This is defined when the organic matter is more complex than that usually involved in these latter electrochemical devices (e.g., sodium acetate or glucose).

$$
E_{r e c}=\left(\int P d t\right) V_{-} \text {int }
$$

where $E_{\text {rec }}\left(\mathrm{J} \mathrm{m}^{-3}\right)$ is recovered energy, $V_{-}$int $\left(\mathrm{m}^{3}\right)$ is the internal volume of s-MFCs and $\int P d t(\mathrm{~J})$ is the integral of generated power over whole time of permanence of AUV in a certain depth.

\section{Results and Discussion}

With the main target of analyzing the performance of s-MFCs, working with a biofilm obtained by marine consortia and using seawater as electrolyte, containing organic matter useful for metabolic activity of electroactive bacteria, voltage trends were measured. Moreover, to demonstrate the capability/effectiveness of all these devices to produce power output, current density trends were thus defined. Figure 2a reports the current density trends of all tested s-MFCs over time, calculated by normalizing with respect to the geometric area $\left(18 \mathrm{~cm}^{2}\right)$. It is possible to define a startup phase during which a substantial increment in energy production is observed for all s-MFCs, which is associated to maximum current density values close to $(294.5 \pm 3.6) \mathrm{mA} \mathrm{m}^{-2},(233.1 \pm 2.1) \mathrm{mA} \mathrm{m}^{-2}$ and $(202.6 \pm 4.1) \mathrm{mA} \mathrm{m}^{-2}$ for the three cells. It is also interesting to notice how all s-MFCs reach these quite stable maximum values whenever seawater is changed and the new 
organic matter is provided. Since overall s-MFCs performance is strictly correlated with the metabolic activity of electroactive bacteria, it was commonly accepted that these current density trends were considered similar. To evaluate overall performance of s-MFCs more deeply, a second phase of experimentation was performed. During this experimental phase, polarization curves obtained for all s-MFCs were directly compared one with the other, as reported in Figure 2b. LSV characterization was performed at the end of the experimental study in the laboratory, leading thus to evaluate and analyze the overall s-MFCs' performance. Open circuit voltage (OCV) values for all s-MFCs were variable in the range from $0.3 \mathrm{~V}$ to $0.4 \mathrm{~V}$. Moreover, it can be noticed that all s-MFCs reached very similar maximum power density values, equal to $(12.34 \pm 0.14) \mathrm{mW} \mathrm{m}^{-2},(10.1 \pm 0.2) \mathrm{mW} \mathrm{m}^{-2}$ and $(10.44 \pm 0.22) \mathrm{mW} \mathrm{m}^{-2}$ respectively. A similar behavior was observed for the short circuit current densities $\left(\mathrm{I}_{\mathrm{scc}}\right)$. LSV measurements allowed estimation of the internal resistance of all s-MFCs, which is equal to $(1.1 \pm 0.3) \mathrm{k} \Omega$.

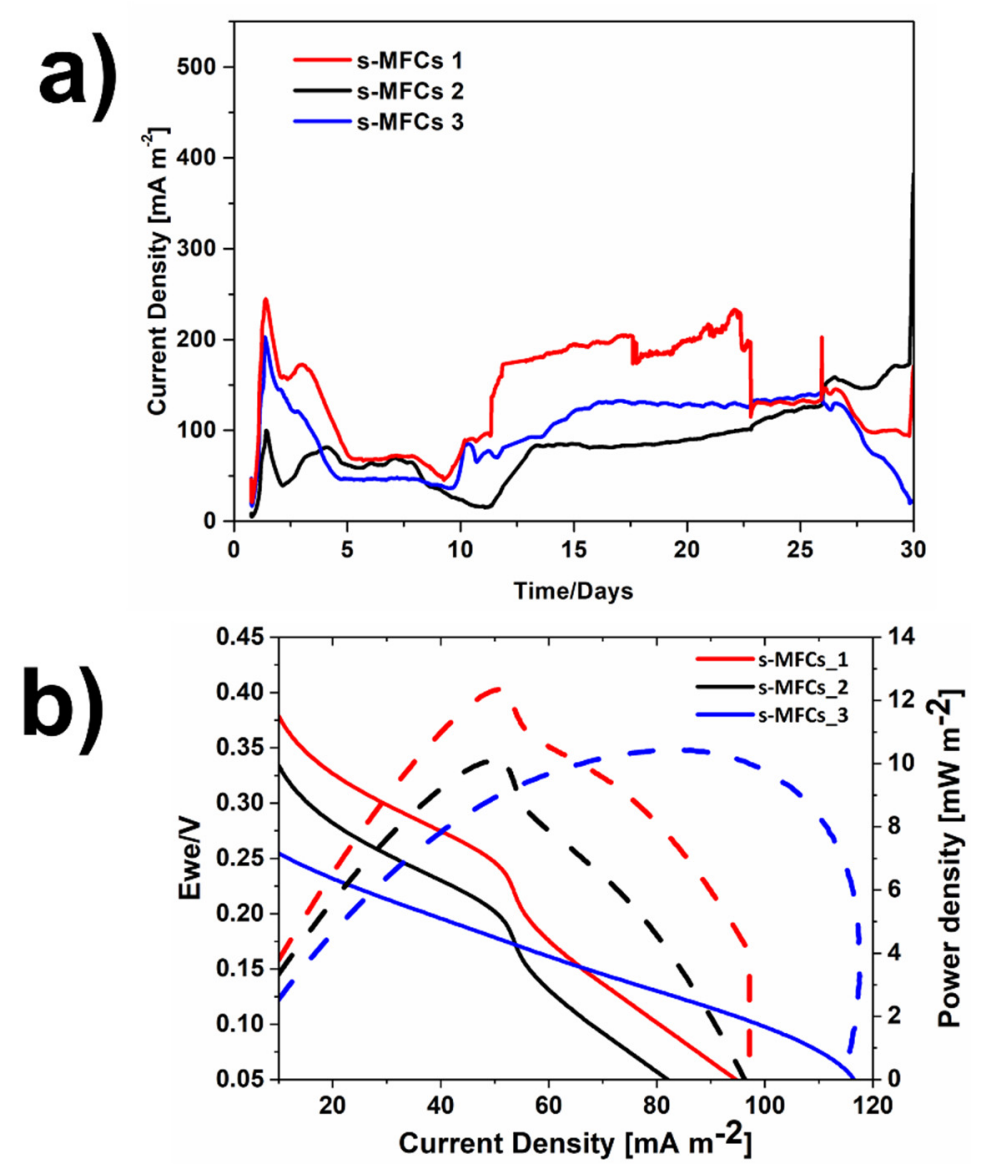

Figure 2. (a) Current density as a function of time during the laboratory tests for all designed s-MFCs. The whole period is equal to 1 month; (b) Polarization curves, obtained by linear sweep voltammetry characterizations, are represented. Red lines and red dots represent I-V curves and power density trends related to s-MFCs 1 ; black lines and dots represent I-V curves and power density trends related to s-MFCs 2; blue lines and blue dots represent I-V curves and power density trends related to s-MFCs 3.

All obtained results confirm that all s-MFCs proved to be quite stable during tests. This consideration demonstrates how much some features selected for the design and development of s-MFCs, such as cylindrical configuration, placement of anode electrodes totally buried into the sediment and the disposition of cathodes electrodes around the outer surface of s-MFCs without the catalyst layer, are efficient in obtaining stable and effective overall device performance. These designed s-MFCs were suitable as MFC-payload and they were mounted in the MFC-payload for the experiments in seawater. The results of the 
two measurement campaigns are presented in Figure 3. The first set of results, exploring a maximum depth of $3 \mathrm{~m}$, is shown in Figure 3a, while the second in which $9 \mathrm{~m}$ of depth were reached is reported in Figure $3 b$.
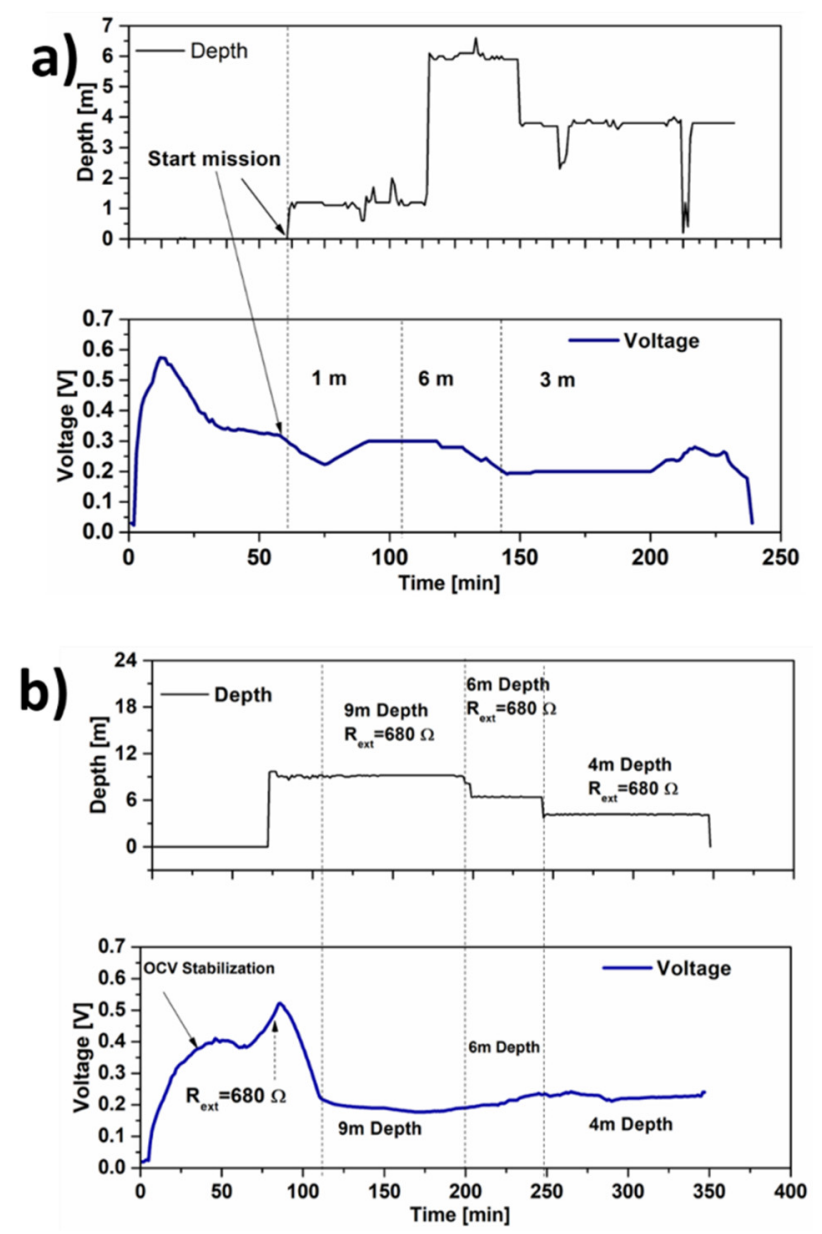

Figure 3. Results of the two measurement campaigns: (a) shows results for a maximum depth of $3 \mathrm{~m}$, (b) reports the behavior of the MFC-payload up to $9 \mathrm{~m}$.

The results demonstrate a high stability of the cylindrical s-MFC integrated in the MFCpayload. The s-MFCs produce electricity continuously during the AUV-glider operation, without any break during AUV-glider movement. In particular, it is possible to define a correlation between the s-MFCs' output parameters with depth, demonstrating thus how the depth can affect the overall s-MFCs' performance. As reported in Figure $3 \mathrm{a}, \mathrm{b}$, it is interesting to notice how the voltage value drops when the depth increases. The reason for this behavior can be explained considering that changes of depth are actually associated with variations of environmental parameters, such as pressure and temperature, the latter being a critical parameter for speeding up or reducing microbial metabolism. Table 2 summarizes the value of voltage, current and power as a function of the analyzed depth. 
Table 2. Measurement campaigns as a function of depth.

\begin{tabular}{cccc}
\hline Depth [m] & Voltage [mV] & Current [mA] & Power [mW] \\
\hline 0 & 440 & 0.647 & 0.285 \\
\hline 1 & 290 & 0.426 & 0.124 \\
\hline 3 & 210 & 0.309 & 0.065 \\
\hline 4 & 220 & 0.324 & 0.071 \\
\hline 6 & 190 & 0.279 & 0.053 \\
\hline 9 & 192 & 0.282 & 0.054 \\
\hline
\end{tabular}

All these latter results are successfully confirmed by introducing and providing the physical parameter of recovered energy $E_{r e c}$ defined as a function of depth, as represented in Figure 4. Since energy recovery is seen as the ratio of the generated integral power and the internal volume of the device $[55,56]$, it was commonly accepted that its variation can be affected by the same factors that normally influence the overall MFCs' performance, such as temperature, oxygen content in seawater, and substrate used as organic matter. In the present work, we defined a correlation between the variation of seawater temperature and energy recovery by using a temperature sensor placed onto an AUV glider. It is possible to appreciate an important decrease of $E_{\text {rec }}$ when the AUV-glider moved from the sea surface to a depth equal to $1 \mathrm{~m}$, varying from $12.85 \mathrm{~J} \mathrm{~m}^{-3}$ to $7.85 \mathrm{~J} \mathrm{~m}^{-3}$, respectively. This significant change of the $E_{r e c}$ can be explained considering that a great temperature variation is registered by the AUV during the first displacement from sea surface ( $0 \mathrm{~m}$ depth) to a depth of $1 \mathrm{~m}$, varying from $24.5^{\circ} \mathrm{C}$ to $18.4^{\circ} \mathrm{C}$. The variation of the recovered energy can therefore be attributed to the influence of the external temperature on bacterial metabolism, as also confirmed in the literature $[55,56]$. On the contrary, as the depth increases (from $1 \mathrm{~m}$ to $9 \mathrm{~m}$ from the sea surface), a slight drop of $E_{\text {rec }}$ is observed, in accordance with the small temperature variation, leading thus to demonstrate the capability of s-MFCs to produce continuously energy also when AUV's parameters and environment conditions change.

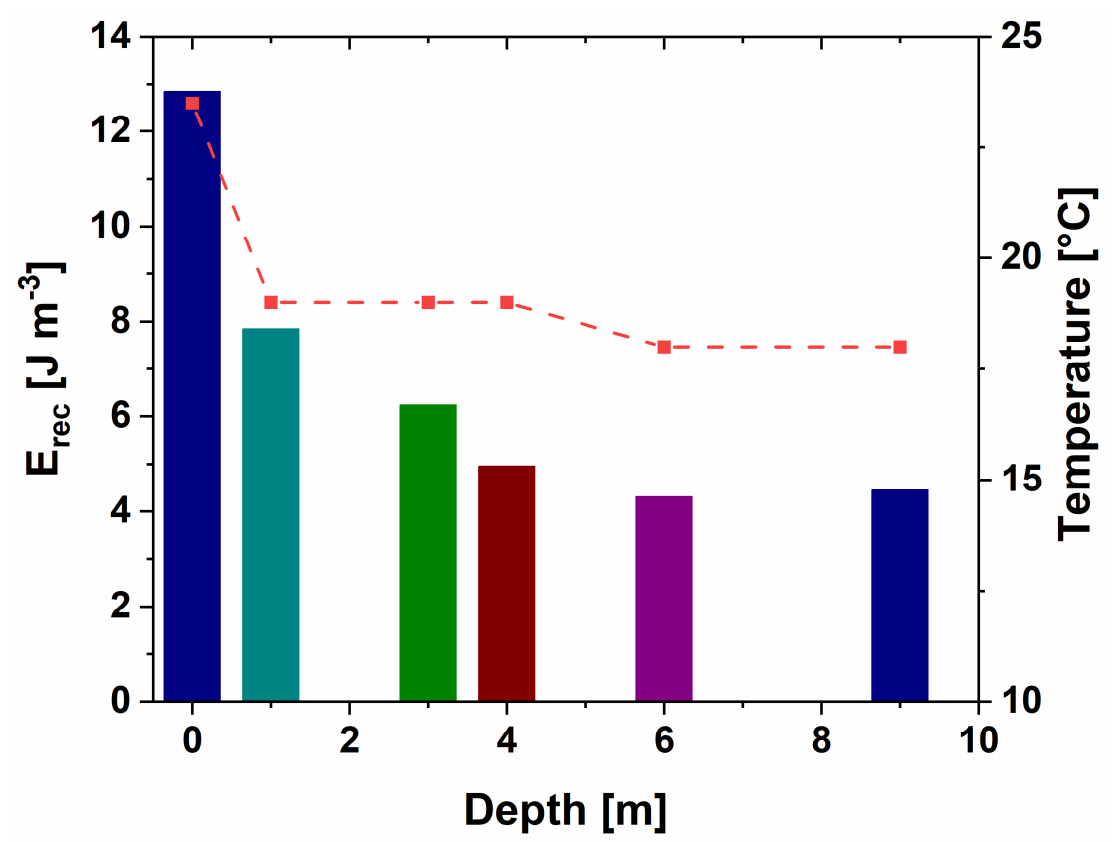

Figure 4. $E_{\text {rec }}$ is shown as a function of the depth reached by the AUV during seawater test. The temperature change with depth is also analyzed, to highlight the dependence of that recovered to the environmental temperature. The time period is equal for each measure, and is equal to the time of permanence of AUV at the certain depth. 
It is very important to observe that during all the tests performed in seawater, no dependence of the output parameters has been observed with navigation conditions. This is an important finding, since it demonstrates that energy production by s-MFCs integrated in AUV systems is decoupled by the navigation of the autonomous vehicle itself, showing the effectiveness of the application of MFC-based technology for advanced systems of environmental analysis. All these latter results demonstrate and confirm the ability of the devices to continuously produce electricity during different AUV operation modes (i.e., depth and speed) while changing environmental conditions (i.e., pressure, temperature and oxygen content) demonstrate that cylindrical s-MFC devices are a robust system that can be successfully used in underwater applications.

\section{Conclusions}

In this work sedimentary microbial fuel cells (s-MFC) have been analyzed as compact and cost-effective tools to be integrated as a payload in an Autonomous Underwater Vehicle (AUV). S-MFCs are indeed able to continuously and autonomously produce renewable and sustainable energy, being the ideal candidate to design new energy payloads, i.e., MFCpayloads, to be integrated in AUVs. The results of this work demonstrate that cylindrical s-MFC using bacteria obtained by in-situ colonization approaches are highly stable, and once integrated in the MFC-payload they ensure continuous production of electricity during different AUV navigation modes. Interestingly, changes in depth are directly reflected in changes of the output parameters, confirming the intrinsic sensitivity of the MFCs to environmental conditions, temperature first of all. Nevertheless, cylindrical s-MFC devices behaved as robust systems that can be successfully used in underwater applications.

Author Contributions: Conceptualization, G.M. and M.Q.; methodology, G.M. and M.Q.; Software, R.M. and A.F.; formal analysis, G.M. and M.Q.; investigation, G.M., A.S. and M.Q.; resources, M.Q., C.F.P., L.S. and S.F.; data curation, G.M., A.S. and M.Q.; writing-original draft preparation, G.M. and M.Q.; writing-review and editing, G.M., M.Q. and A.F.; visualization, G.M., C.F.P. and M.Q.; supervision and project administration, A.S., C.F.P. and M.Q.; funding acquisition, C.F.P. and R.M. All authors have read and agreed to the published version of the manuscript.

Funding: This research received no external funding.

Institutional Review Board Statement: Not applicable.

Informed Consent Statement: Not applicable.

Acknowledgments: The research activity has been carried out in the framework of a cooperation between the Italian Ministry of Defense and the US Department of Defense; in this context, the authors wish to acknowledge the support received by the Secretariat General of Defense of the Italian MoD that co-founded the research activity. The Authors acknowledge Andrea Piscitelli from Microla Optoelectronics S.r.l. for the fruitful discussion and collaboration.

Conflicts of Interest: The authors declare no conflict of interest.

\section{References}

1. Bellingham, J. Autonomous Underwater Vehicles (AUVs); MIT Sea Grant: Cambridge, MA, USA, 2001. [CrossRef]

2. Bellingham, J.G.; Goudey, C.; Consi, T.R.; Chryssostomidis, C. A small long range vehicle for deep ocean exploration. In Proceedings of the Second (1992) International Offshore and Polar Engineering Conference, San Francisco, CA, USA, 14-19 June 1992; pp. 151-159.

3. Yazdani, A.M.; Sammut, K.; Yakimenko, O.; Lammas, A. A survey of underwater docking guidance systems. Robot. Auton. Syst. 2020, 124, 1-21. [CrossRef]

4. Huang, H.; Tang, Q.; Li, J.; Zhang, W.; Bao, X.; Zhu, H.; Wang, G. A review on underwater autonomous environmental perception and target grasp, the challenge of robotic organism capture. Ocean. Eng. 2020, 195, 1-11. [CrossRef]

5. Blidberg, D.R. The development of autonomous underwater vehicles (AUV); a brief summary. IEEE ICRA $2001,4,1$.

6. Zhao, S.; Yuh, J. Experimental study on advanced underwater robot control. IEEE Trans. Robot. 2005, 21, 695-703. [CrossRef]

7. Zeng, Z.; Lian, L.; Sammut, K.; He, F.; Tang, Y.; Lammas, A. A survey on path planning for persistent autonomy of autonomous underwater vehicles. Ocean. Eng. 2015, 110, 303-313. [CrossRef] 
8. Christ, R.D.; Wernli, R.L., Sr. The ROV Manual: A User Guide for Remotely Operated Vehicles; Butterworth-Heinemann: Amsterdam, The Netherlands, 2013.

9. Yuh, J. Design and Control of Autonomous Underwater Robots: A Survey. Auton. Robot. 2000, 8, 7-24. [CrossRef]

10. Stewart, M.S.; Pavlos, J. A Means to Networked Persistent Undersea Surveillance. Submarine Technology Symposium; University of Washington: Tacoma, WA, USA, 2006.

11. Stokey, R.P.; Roup, A.; Von Alt, C.; Allen, B.; Forrester, N.; Austin, T.; Goldsborough, R.; Purcell, M.; Jaffre, F.; Packard, G.; et al. Development of the REMUS 600 autonomous underwater vehicle. In Proceedings of the IEEE Oceans 2005 Conference, Washington, DC, USA, 17-23 September 2005; pp. 1301-1304.

12. Bradley, A.M.; Feezor, M.D.; Singh, H.; Sorrell, F.Y. Power systems for autonomous underwater vehicles. IEEE J. Ocean. Eng. 2001, 26, 526-538. [CrossRef]

13. Hagen, P.; Storkersen, N.; Vestgård, K.; Kartvedt, P. The HUGIN 1000 autonomous underwater vehicle for military applications. In Proceedings of the IEEE OCEANS 2003 Conference, 22-26 September. 2003, San Diego, CA, USA; pp. 1141-1145.

14. Ferguson, J.; Pope, A. Explorer-a modular AUV for commercial site survey. In Proceedings of the 2000 IEEE International Symposium on Underwater Technology, Tokyo, Japan, 23-26 May 2000; pp. 129-132.

15. Iqdal, J.; Khan, Z.H. The potential role of renewable energy sources in robot's power system: A case study of Pakistan. Renew. Sustain. Energy Rev. 2017, 75, 106-122.

16. Tyagi, V.; Rahim, N.A.; Rahim, N.A.; Jeyraj, A.; Selvaraj, L. Progress in solar PV technology: Research and achievement. Renew. Sustain. Energy Rev. 2013, 20, 443-461. [CrossRef]

17. Moosavian, S.; Rahim, N.; Selvaraj, J.; Solangi, K. Energy policy to promote photovoltaic generation. Renew. Sustain. Energy Rev. 2013, 25, 44-58. [CrossRef]

18. Anusuya, S.; Thiruveni, M.M. Smart battery charger for solar-powered line follower robotic vehicle. Int. J. Comput. Sci. Mob. Comput. 2014, 3, 603-608.

19. Lever, J.H.; Ray, L.; Streeter, A.; Price, A. Solar power for an Antarctic rover. Hydrol. Process. 2006, 20, 629-644. [CrossRef]

20. Ackerman, E. AeroVironment's Mola Robot Flies Underwater on Solar Power, IEEE Spectrum. 2012. Available online: https: //spectrum.ieee.org/automaton/robotics/robotics-hardware/aerovironments-mola (accessed on 23 June 2021).

21. GHJTL Beatman. Wave glider-A coastal restoration platform. A Liquid Robotics®White Paper, 12 February 2012.

22. Khan, N.; Kalair, A.; Abas, N.; Haider, A. Review of ocean tidal, wave and thermal energy technologies. Renew. Sustain. Energy Rev. 2017, 72, 590-604. [CrossRef]

23. Blidberg, D.R.; Chappel, S.; Jalbert, J.C. Long endurance sampling of the ocean with solar powered AUV's. In Proceedings of the 5th IFAC/EURON Symposium on Intelligent Autonomous Vehicles Instituto Superior Tecnico, Lisboa, Portugal, 5-7 July 2004.

24. Daniel Steinberg, A.B.; Friedman, A.; Jakuba, M.; Pizarro, O.; Williams, S. Analysis of propulsion methods long-range AUVs. Mar. Technol. Soc. J. 2010, 44, 46-65. [CrossRef]

25. Naveed, K.; Khan, Z.H.; Salman, M.; Malik, M.B.; Ali, M.U. Adaptive Trajectory Control of Wheeled Mobile Robot (WMR). In Proceedings of the IEEE International Conference on Modeling and Simulation (ICOMS), Melbourne, Australia, 25-27 June 2013.

26. Manley, J.E. Unmanned surface vehicles, 15 years of development. In Proceedings of the IEEE Unmanned Surface Vehicles, 15 Years of Development, Kobe, Japan, 8-11 April 2008; pp. 1-4.

27. Mendez, A.; Leo, T.J.; Herreros, M.A. Current State of Technology of Fuel Cell Power Systems for Autonomous Underwater Vehicles. Energies 2014, 7, 4676-4693. [CrossRef]

28. Ieropoulos, I.A.; Greenman, J.; Melhuish, C.; Horsfield, I. Microbial Fuel Cells for Robotics: Energy Autonomy through Artificial Symbiosis. Chem. Sustain. Chem. 2012, 5, 1020. [CrossRef] [PubMed]

29. Logan, B.E. Microbial Fuel Cells; John Wiley \& Sons: Hoboken, NJ, USA, 2008.

30. Trapero, J.R.; Horcajada, L.; Linares, J.J.; Lobato, J. Is microbial fuel cell technology ready? An economic answer towards industrial commercialization. Appl. Energy 2017, 185, 698-707. [CrossRef]

31. Christwardana, M.; Frattini, D.; Accardo, G.; Yoon, S.P.; Kwon, Y. Early-stage performance evaluation of flowing microbial fuel cells using chemically treated carbon felt and yeast biocatalyst. Appl. Energy 2018, 222, 369-382. [CrossRef]

32. Han, H.-X.; Shi, C.; Yuan, L.; Sheng, G.-P. Enhancement of methyl orange degradation and power generation in a photoelectrocatalytic microbial fuel cell. Appl. Energy 2017, 204, 382-389. [CrossRef]

33. Pandey, P.; Shinde, V.N.; Deopurkar, R.L.; Kale, S.P.; Patil, S.A.; Pant, D. Recent advances in the use of different substrates in microbial fuel cells toward wastewater treatment and simultaneous energy recovery. Appl. Energy 2016, 168, 706-723. [CrossRef]

34. Tanikkul, P.; Pisutpaisal, N. Membrane-less MFC based biosensor for monitoring wastewater quality. Int. J. Hydrog. Energy 2018, 43, 483-489. [CrossRef]

35. Rahimnejad, M.; Ghoreyshi, A.A.; Najafpour, G.; Jafary, T. Power generation from organic substrate in batch and continuous flow microbial fuel cell operations. Appl. Energy 2011, 88, 3999-4004. [CrossRef]

36. Garino, N.; Sacco, A.; Castellino, M.; Muñoz-Tabares, J.A.; Chiodoni, A.; Agostino, V.; Margaria, V.; Gerosa, M.; Massaglia, G.; Quaglio, M. Microwave-Assisted Synthesis of Reduced Graphene Oxide/ $\mathrm{SnO}_{2}$ Nanocomposite for Oxygen Reduction Reaction in Microbial Fuel Cells. Acs Appl. Mater. Interfaces 2016, 8, 4633-4643. [CrossRef] [PubMed]

37. Ewing, T.; Ha, P.T.; Beyenal, H. Evaluation of long-term performance of sediment microbial fuel cells and the role of natural resources. Appl. Energy 2017, 192, 490-497. [CrossRef] 
38. Song, T.-S.; Jiang, H.-L. Effects of sediment pretreatment on the performance of sediment microbial fuel cells. Bioresour. Technol. 2011, 102, 10465-10470. [CrossRef] [PubMed]

39. Tender, L.M.; Gray, S.A.; Groveman, E.; Lowy, D.A.; Kauffman, P.; Melhado, J.; Tyce, R.C.; Flynn, D.; Petrecca, R.; Dobarro, J. The first demonstration of a microbial fuel cell as a viable power supply: Powering a meteorological buoy. J. Power Sources 2008, 179, 571-575. [CrossRef]

40. Massaglia, G.; Margaria, V.; Sacco, A.; Tommasi, T.; Pentassuglia, S.; Ahmed, D.; Mo, R.; Pirri, C.F.; Quaglio, M. In situ continuous current production from marine floating microbial fuel cells. Appl. Energy 2018, 230, 78-85. [CrossRef]

41. Olias, L.G.; Di Lorenzo, M. Microbial fuel cells for in-field water quality monitoring. Rsc Adv. 2021, 11, 16307-16317. [CrossRef]

42. Abbas, S.Z.; Rafatullah, M.; Ismail, N.; Syakir, M.I. A review on sediment microbial fuel cells as a new source of sustainable energy and heavy metal remediation: Mechanisms and future prospective. Int. J. Energy Res. 2017, 41, 1242-1264. [CrossRef]

43. Algar, C.K.; Howard, A.; Ward, C.; Wanger, G. Sediment microbial fuel cells as a barrier to sulfide accumulation and their potential for sediment remediation beneath aquaculture pens. Sci. Rep. 2020, 10, 13087. [CrossRef] [PubMed]

44. Khan, M.M.; Min, B.-K.; Cho, M.H. Microbial fuel cell assisted band gap narrowed $\mathrm{TiO}_{2}$ for visible light-induced photocatalytic activities and power generation. Sci. Rep. 2018, 8, 1-12. [CrossRef]

45. Khan, M.E.; Han, T.H.; Khan, M.M.; Karim, M.R.; Cho, M.H. Environmentally Sustainable Fabrication of Ag@g-C $3 \mathrm{~N}_{4}$ Nanostructures and Their Multifunctional Efficacy as Antibacterial Agents and Photocatalysts. Acs Appl. Nano Mater. 2018, 1, $2912-2922$. [CrossRef]

46. Wilkinson, S. "Gastrobots"-Benefits and Challenges of Microbial Fuel Cells in Food Powered Robot Applications. Auton. Robot. 2000, 9, 99-111. [CrossRef]

47. Ieropoulos, I.; Melhuish, C.; Greenman, J.; Horsfield, I. EcoBot-II: An artificial agent with a natural metabolism. Int. J. Adv. Robot. Syst. 2005, 2, 295-300. [CrossRef]

48. Ieropoulos, I.; Greenman, J.; Melhuish, C.; Horsfield, I. EcoBot-III-A Robot with Guts. ALIFE 2010, 733, e40.

49. Hong, S.W.; Chang, I.S.; Choi, Y.S.; Chung, T.H. Experimental evaluation of influential factors for electricity harvesting from sediment using microbial fuel cell. Bioresour. Technol. 2009, 100, 3029-3035. [CrossRef]

50. Hsu, L.; Mohamed, A.; Ha, P.T.; Bloom, J.; Ewing, T.; Arias-Thode, M.; Chadwick, B.; Beyenal, H. The Influence of Energy Harvesting Strategies on Performance and Microbial Community for Sediment Microbial Fuel Cells. J. Electrochem. Soc. 2017, 164, H3109-H3114. [CrossRef]

51. Wetser, K.; Dieleman, K.; Buisman, C.; Strik, D. Electricity from wetlands: Tubular plant microbial fuels with silicone gas-diffusion biocathodes. Appl. Energy 2017, 185, 642-649. [CrossRef]

52. Massaglia, G.; Fiorello, I.; Sacco, A.; Margaria, V.; Pirri, C.F.; Quaglio, M. Biohybrid Cathode in Single Chamber Microbial Fuel Cell. Nanomaterials 2019, 9, 36-47. [CrossRef]

53. Nastro, R.A.; Jannelli, N.; Minutillo, M.; Guida, M.; Trifuoggi, M.; Andreassi, L.; Facci, A.L.; Krastev, V.K.; Falcucci, G. Performance evaluation of Microbial Fuel Cells fed by solid organic waste: Parametric comparison between three generations. Energy Procedia 2017, 105, 1102-1108. [CrossRef]

54. Jannelli, N.; Nastro, R.A.; Cigolotti, V.; Minutillo, M.; Falcucci, G. Low pH, high salinity: Too much for microbial fuel cells? Appl. Energy 2017, 192, 543-550. [CrossRef]

55. Aguzzi, J.; Costa, C.; Calisti, M.; Funari, V.; Stefanni, S.; Danovaro, R.; Gomes, H.I.; Vecchi, F.; Dartnell, L.R.; Weiss, P.; et al. Research Trends and Future Perspectives in Marine Biomimicking Robotics. Sensors 2021, 21, 3778. [CrossRef]

56. Capodaglio, A.G.; Molognoni, D.; Dallago, E.; Liberale, A.; Cella, R.; Longoni, P.; Pantaleoni, L. Microbial Fuel Cells for Direct Electrical Energy Recovery from Urban Wastewaters. Sci. World J. 2013, 2013, 634738. [CrossRef] [PubMed]

57. Massaglia, G.; Frascella, F.; Chiadò, A.; Sacco, A.; Marasso, S.L.; Cocuzza, M.; Pirrin, C.F.; Quaglio, M. Electrospun Nanofibers: From Food to Energy by Engineered Electrodes in Microbial Fuel Cells. Nanomaterials 2020, 10, 523-534. [CrossRef]

58. Heidrich, E.S.; Wade, M.J.; Sloan, W.T.; Quince, C.; Curtis, T.P. Temperature, inocula and substrate: Contrasting electroactive consortia, diversity and performance in microbial fuel cells. Bioelectrochemistry 2018, 119, 43-50. [CrossRef]

59. Jadhav, G.; Ghangrekar, M. Performance of microbial fuel cell subjected to variation in $\mathrm{pH}$, temperature, external load and substrate concentration. Bioresour. Technol. 2009, 100, 717-723. [CrossRef] [PubMed]

60. Gadkari, S.; Fotnmorin, J.M.; Yu, E.; Sadhukhan, J. Influence of temperature and other system parameters on microbial fuel cells performance: Numerical and experimental investigation. Chem. Eng. J. 2020, 388, 124176. [CrossRef]

61. Margaria, V.; Tommasia, T.; Pentassuglia, S.; Agostino, V.; Sacco, A.; Armato, C.; Chiodoni, A.; Schilirò, A.; Quaglio, M. Effects of $\mathrm{pH}$ variations on anodic marine consortia in a dual chamber microbial fuel cell. Int. J. Hydrog. Energy 2017, 42, 1820-1829. [CrossRef] 